\title{
BIOMARKERS OF ACUTE KIDNEY INJURY AND THEIR ROLE IN CLINICAL PATIENT MANAGEMENT
}

\author{
Ecem Büşra Deġer ${ }^{1 *}$, Enver Arslan ${ }^{1}$, Müslim Doğan Deg̉er ${ }^{2}$, and Oktay Kaya ${ }^{1}$ \\ ${ }^{1}$ Department of Physiology, Faculty of Medicine, Trakya University, Edirne, Turkey \\ ${ }^{2}$ Department of Urology, Edirne Sultan 1. Murat State Hospital, Edirne, Turkey
}

Acute kidney injury (AKI) is a common public health problem and has a significant impact on cardiovascular disease, mortality and increased hospital costs. Also, AKI can progress to chronic kidney disease (CKD). Therefore, early diagnosis is very important for AKI. Serum creatinine (SCr) is a well-known biomarker in the diagnosis of AKI. However, changes in SCr levels are insufficient in early diagnosis so, new biomarkers are needed. Because of that, the search for biomarkers for the early detection of AKI is an ongoing process. In recent years, early diagnosis, prognostic and predictive biomarkers have been discovered to replace or support SCr in the diagnosis of AKI. New biomarkers can help early diagnosis and effective management of AKI. Since there are many biomarkers, when and under which condition these biomarkers should be used cause confusion. In this review, we aimed to construct and ease to use classification of these AKI biomarkers and summarize the current literature. We have divided the biomarkers into two main categories: renal and non-renal origin. Then, we have classified the biomarkers of renal origin as glomerular, tubular and unknown renal site. We have also described the clinical use of these biomarkers for diagnosis and prognosis.

Biomed Rev 2020; 31: 11-29

Keywords: renal injury, clinical usage, early diagnosis, prognosis

\section{INTRODUCTION}

Acute kidney injury (AKI) is a common public health problem that often occurs in patients followed up in the hospital. Although a significant proportion of those affected reside in low- and middle-income countries, they are linked to short- term mortality and increased healthcare costs in high-income countries too (1). A systematic review of 312 cohort studies covering 49 million patients showed that 1 in 5 adults and 1 in every 3 children had AKI during hospital care. Mortality associated with AKI has been reported to be $23.9 \%$ in adults

*Correspondence to: Dr. Ecem Büşra Deġer, Trakya Üniversitesi Tip Fakültesi, Fizyoloji Anabilim Dalı, Balkan Yerleşkesi, D Blok Kat:2, 22030 Edirne, Turkey

E-mail: ecemberdinc@gmail.com 
and $13.8 \%$ in children (2). In the United States, about 300,000 people die annually due to AKI, and 1.2 million people develop AKI during their hospitalization, resulting in an average 3.5day increase in hospitalization. The annual cost of inpatient care for AKI is estimated at 1.02 billion GBP, slightly above $1 \%$ of the total budget of the National Health System in the UK. The lifetime cost of post-discharge care for people who have undergone AKI in the hospital between 2010 and 2011 is estimated to be 179 million GBP (2).

Although AKI is considered to be a self-limiting condition in the early stages, it is known to be associated with long-term consequences such as progression to chronic kidney injury or end-stage renal failure, cardiovascular diseases and death $(1,3)$. International criteria for the diagnosis and staging of acute kidney injury have facilitated the characterization of short and long-term health consequences of AKI.

Early diagnosis is very important for AKI with specific treatment chances to reverse the damaging process in kidneys (4). In the mild damage period, intact nephrons compensate and protect glomerular filtration rate (GFR). Only when this compensation is exceeded, GFR begins to decrease. This subclinical stage cannot be diagnosed with creatinine level. Creatinine level can be affected by many non-kidney factors and increases after a significant part of the nephrons are affected (5). Additional tools may be required to diagnose AKI, especially since creatinine and urine output values can be misleading in situations such as excessive fluid overload or decreased circulation volume, muscle loss, and sepsis (4).

Recently, significant progress has been made in the detection and validation of new biomarkers to replace or support serum creatinine ( $\mathrm{SCr}$ ) in the diagnosis of AKI. In this review, we aimed to summarize these markers that indicate kidney injury, and that have diagnostic and prognostic values.

\section{BIOMARKERS WITH RENAL GLOMERULAR ORIGIN}

Soluble urokinase plasminogen activator receptor (su$\boldsymbol{P A R}$ ) is a circulating glycosyl-phosphatidylinositol-bound membrane protein, the soluble form of the urokinase-type plasminogen activator receptor (UPAR). It is expressed in endothelial cells, podocytes and immunological cells such as monocyte-lymphocyte (6). Circulating suPAR play a role in the immune activation, inflammation and physiopathology of kidney disease $(7,8)$. SuPAR causes podocyte dysfunction, glomerular damage and proteinuria with the pathological activation of $v ß 3$ integrin expressed in podocytes as a result of high levels of long-term circulation (9-11). It also plays a role in the development of AKI pathogenesis, by changing the proximal tubular mitochondrial energy metabolism, making the kidney susceptible to damage through increased oxidative stress. SuPAR increases before AKI and predicts that the risk of increased AKI. It is thought to have a pathogenic role in the development of AKI. SuPAR may serve as a marker of infection and was used for therapeutic purposes in several studies $(6,12,13)$.

\section{BIOMARKERS WITH RENAL TUBULAR ORIGIN}

KIM-1 is a transmembrane protein, which is secreted at low levels in the physiologically healthy kidney, increasing proportionally with age and released from the proximal tubule after renal tubular injury (14). It provides kidney recovery and tubular regeneration with its apoptotic body clearance mechanism $(15,16)$. Its increase in tubular damage is detected within 24 hours (17) and its expression reaches its peak after 2-3 days (18). This early increase of KIM-1 is precious in the early diagnosis of AKI since it is before creatinine elevation (19).

Liver-type fatty acid binding protein $(L-F A B P)$ is a cytosolic protein that binds long chain fatty acids and transports them to the mitochondria or peroxisomes, where the fatty acids are metabolized through beta-oxidation. Because it binds to long-chain fatty acids and oxidation products, it acts as an antioxidant against the toxic effects of oxidative intermediates on the cell. It is expressed in the liver, pancreas, stomach, intestine, lung and kidney (20). It is expressed in the proximal tubule in the kidney, thrown into the tubular lumen together with the toxic peroxisomal products to which it is attached and absorbed through the proximal tubule through megalin mediated endocytosis (21); it is not normally detected in urine. Its expression increases with the degree of acute kidney damage and appears in urine. Increased L-FABP expression is thought to protect the kidney against tubular and oxidative damage (22). Hence, it is a biomarker with therapeutic potential that can be used in the early diagnosis of AKI $(23,24)$.

NAG ( $N$-acetyl- $\beta$-D-glucosaminidase) is an enzyme produced by lysosomes of high molecular weight renal proximal tubular cells. Due to the large molecular weight $(>130-\mathrm{kDa})$, it cannot be filtered from glomeruli. Therefore, an increase in urine indicates proximal tubule damage (23). It can be used in early diagnosis of AKI since the post-injury increase is before the microalbumin begins to appear in the urine and increase in $\operatorname{SCr}(25,26)$.

Tissue Inhibitor of Metalloproteinases-2 (TIMP-2) and Insulin-like Growth Factor - Binding Protein 7 (IGFBP7), 
known as NephroCheck, are G1 cell cycle arrest markers. TIMP-2 proteins are endogenous inhibitor of the matrix metalloproteinases and suppress proliferation of endothelial cells in response to angiogenic factors. IGFBP7 regulates the binding of IGF to its receptors and the availability of insulin-like growth factors in tissues. TIMP-2 and IGFBP7 are expressed in the early stages of cellular stress after acute injury, from the TIMP-2 distal tubule and IGFBP7 proximal tubule (although various parts of the nephron can produce both markers) in response to DNA damage and other damage. As a protective mechanism, they stop the cell cycle by increasing and activating p53, p21 and p27. In this way they block the division of damaged cells $(24,27)$. They undergo glomerular filtration and appear in urine (28). The increase in its expression indicates the stress of the kidney rather than damage (29). After exposure to stressors (e.g., nephrotoxins), rapid increase long before creatinine increase has an important role in identifying individuals at risk of AKI $(30,31)$. Urinary TIMP-2 and IGFBP7 combination, NephroCheck, is a FDAapproved biomarker useful for early identification of acute kidney damage, predicting irreversible AKI, kidney healing and long-term kidney outcome (32).

Alpha-glutathione S-transferase ( $\alpha$-GST) is a member of the family of cytoplasmic enzymes that detoxify various compounds by conjugating them with glutathione. It increases tubular cells' resistance to stressful conditions. The $\alpha$-GST produced in the proximal tubule accumulates when the integrity of the kidney tubules is impaired and becomes detectable in the urine $(22,33)$. Due to it is urinary proximal tubule enzyme and its increase after AKI, $\alpha$-GST can be used in early diagnosis in combination with other biomarkers, if not alone.

$\mathbf{I L - 1 8}$ is a proinflammatory cytokine that plays a role in innate and acquired immunity. IL-18 is produced by renal tubular cells, macrophages, keratinocytes, osteoblasts, dentritic cells and intestinal epithelial cells (24). Expression from proximal tubules increases after acute kidney injury, and urine IL-18 increases within the first 6 hours, 1 day before SCr increase (34). Urine IL-18 is useful for predicting the early diagnosis and prognosis of AKI $(22,35,36)$.

$\mathrm{Na}^{+} / \mathrm{H}^{+}$exchange regulatory factor 1 (NHERF1) is a member of PDZ scaffolding protein family which anchors it to the cytoskeleton in the subapical plasma membrane region (37). NHERF1 is expressed in all epithelial cells, but is an important scaffold protein for transport proteins, especially in proximal tubule cells. NHERF1 plays a major role in regulating ion transport and defining the proximal tubule brush border membrane composition $(37,38)$. In NHERF1 deficiency, a modified transcription pattern and worse survival have been observed in proximal tubule cells, and this deficiency or loss has been shown to increase susceptibility to acute kidney injury (39). Bushau-Sprinkle et al (39) published the first study investigating the role of NHERF1 in cisplatin-induced AKI, and reported that NHERF1 expression can be used as a biomarker for susceptibility to AKI or as an innovative treatment to protect against cisplatin-induced AKI.

Netrin-1 plays a role in the regulation of angiogenesis, cell migration, tissue morphogenesis and inflammation and is a multifunctional laminin-related protein known as a neuronal guidance protein (40). It is expressed in many tissues, including kidney tubule cells, primarily in the nervous system (41). Its expression increases in proximal tubular epithelial cells after acute kidney injury and can be used in the early diagnosis of AKI since this increase is prior to $\mathrm{SCr}(20)$. However, more studies are needed to use this biomarker in the early diagnosis of AKI.

Matrix metalloproteinases (MMPs) are a large family of proteinases containing neutral endopeptidases that play a role in various cellular processes and in the remodeling of the extracellular matrix. Its activities are regulated by endogenous tissue inhibitors of metalloproteinases (TIMPs) and various mechanisms. Abnormal expressions cause kidney pathologies (42). Although many MMPs (such as MMP-2, MMP-8, MMP-7, MMP-9, MMP-10) have been associated with AKI, MMP-7 stands out. MMP-7, is the smallest matrix metalloproteinase, predominantly localized in renal tubular epithelium, is synthesized as an inactive zymogen, it is secreted zinc- and calcium-dependent endopeptidase and can be easily excreted in urine $(43,44)$. It takes part in processes such as tissue remodeling, apoptosis and inflammation. It is generally not detected in normal renal renal tubular epithelium. MMP-7 is induced in injured tubules (in predominantly proximal tubules) by activation of intrarenal Wnt / beta-catenin after AKI and relieves apoptosis by breaking FasL $(45,46)$. It has a protective role in AKI by alleviating kidney damage and promoting tubular regeneration $(46,47)$. It is a new biomarker that can be used in the early diagnosis and prognosis of AKI because it increases after AKI and is useful in predicting the risk of AKI (43, 46-48).

Midkine (MK) is a multifunctional heparin-binding growth factor, induced by oxidative stress. It has biological roles such as cell growth and survival, migration and chemotaxis (49). Along with many kidney pathologies, cancer development is 
associated with tissue inflammation and neuronal development. It does not undergo glomerular filtration as it is found in serum as high molecular weight complexes $(250 \mathrm{kD})$ with $\mathrm{MK}$ binding proteins. Therefore, it is rarely seen in urine in healthy individuals (50). Expressed from low levels of proximal tubules in the healthy kidney, MK is induced from damaged tubules in the early phase after acute kidney injury, with one of the mechanisms of endothelial dysfunction involving inflammation, oxidative stress and activation of the renin-angiotensin system mechanisms. As a result of MK induction, AKI is exacerbated by an increase in leukocyte infiltration into the tubules (50-52). It is a biomarker that can be used in the early diagnosis and as a preventive drug target due to the increase in the early phase, high sensitivity and specificity before $\mathrm{SCr}$ increase after AKI $(26,50,53,54)$.

MicroRNAs (miRNAs, miR) are small endogenous molecules belonging to the non-coding RNA class, about 18-25 nucleotides in length, that combine with transcriptional levels of messenger RNAs to regulate various gene expression. They control the expression of a large number of proteins through many targets and play a role in apoptosis, proliferation, angiogenesis and inflammatory processes (55). It also participates in many physiological and pathological processes such as embryonic development, epithelial cell polarity, hematopoietic system differentiation and nervous system development (56). Dysregulation of miRNAs are associated with many kidney diseases; kidney carcinoma, nephropathies, acute and CKD, graft rejection (57). Abnormally expressed miRNAs play an important role in the development and progression of AKI. Hence, many miRNA are being studied. Especially urinary and plasma miRNA-21 concentrations after renal tubular injury have an important potential in detecting AKI and their progression $(58,59)$. MiRNAs that can be detected in urine, serum, plasma and kidney tissue are considered as potential biomarkers because they show an appropriate change in the degree of injury (60).

Angiotensinogen (AGT) is an amino acid that plays an important role in the renin - angiotensin system (RAS) and leads to the formation of angiotensin I. It is produced in the kidney by proximal tubule cells and thick ascending limb of Henle (61). Due to its high molecular weight (65 kD), it is not filtered (62). Detection in urine is due to intra-renal RAS origination rather than systemic RAS activation and it occurs by being released to the tubular lumen $(62,63)$. UAGT is upregulated in tubular cells after AKI and correlated with intra-renal RAS activation and severity of kidney damage (61,
64). UAGT is a biomarker indicating kidney damage that can be used for early detection of AKI and prediction of chronic kidney disease earlier than SCr and proteinuria (65-67), as well as to estimate the probability of recovery from AKI (61).

Sodium/Hydrogen exchanger isoform (NHE3) is the most abundant sodium transporter in renal tubule and it is localized in cortical proximal tubules and medullary thick ascending limb of Henle. NHE3 is in charge of proximal reabsorbtion of $60-70 \%$ of filtered sodium from the urine (68). Normally, NHE3 is not found in the urine; however, abnormal elevations have been identified in critically ill patients with AKI (69). Du Cheyron et al (69) also reported that urinary NHE3 protein may be useful to differentiate acute tubular necrosis, prerenal azotemia, and intrinsic AKI other than acute tubular necrosis. In addition, NHE3 was shown that is more valuable than to RBP to differentiate pre-renal AKI and ATN and correlated positively with $\mathrm{SCr}$ concentration (70). In conclusion, according to AKI studies, urine NHE3 protein may be a new, sensitive and specific marker of AKI (71).

Neutrophil gelatinase-associated lipocalin (NGAL) is a member of the lipocalin superfamily, which was first discovered in neutrophil granules. Also known as lipocalin 2. It is found in a large number of human tissues -e.g. kidney epithelium, liver, respiratory tract, salivary gland, stomach, colon, prostate and uterus. It is found at a higher level in women than men and increases with age (21). It is found in proximal and distal tubular epithelial cells in the kidney and is responsible for iron traffic within these epithelium (72). The plasma NGAL level increases as it is released from neutrophils during inflammation or infection. Therefore, the urine level should be used to assess acute kidney damage. It detects kidney damage before serum urea-creatinine increases. It also appears before the increase of NAG and $\beta-2$ microglobulin used in the early diagnosis of AKI. Thus, it diagnoses early stage AKI, in which kidney damage is reversible $(24,73)$.

Clusterin is a glycosylated protein found in apoptotic and antiapoptotic pathways in many organ systems (24). It has various cellular biological activities; lipid recycling, cell protection, cell adhesion and aggregation (74). It is found in tubules in the kidney and has an antiapoptotic effect. Increased gene expression occurs after acute tubular damage (24). It is important in detecting tubule damage due to it is not being found in glomeruli and free filter. Although it is also associated with distal tubule and collecting duct damage besides proximal tubule damage, it is more valuable than BUN and $\mathrm{SCr}$ in early detection of proximal tubule damage. Clusterin 
levels are proportional to the degree of proximal tubule damage $(75,76)$. Thus, clusterin, like KIM-1, is one of the early markers in detecting proximal tubular damage.

Uromodulin is a glycoprotein, also known as TammHorsfall protein, located in the thick ascending limb of the loop of Henle and distal tubule of the kidneys. Uromodulin is secreted into urine, which is also the most abundant excreted urine protein (77). One of the most important functions of uromodulin in the kidney is its protective role in the experimental models of AKI $(78,79)$. This protective effect against AKI results from the immunomodulatory function of uromodulin. Therefore, it downregulates inflammation both systemically and in the kidney. At the begining of injury in experimental models of AKI, the expression of uromodulin significantly decreased. Decreased uromodulin suggests that early AKI causes uromodulin deficiency in the kidney (80).

Osteopontin (OPN) is a phosphorylated glycoprotein which is identified in bone tissue. It is expressed in several tissues but produced in kidneys (especially distal tubule and loop of Henle) and secreted into the urine (81). Osteopontin is reported in lots of human studies that it could be a novel biomarker for several kidney diseases (82). It has been found to be a promising marker in patients with acute kidney injury who need renal replacement therapy and it is related with sepsis and renal replacement in these patients (83). Clinical and experimental studies have enounced that OPN can supply survival signals and prevent apoptosis in tubular epithelial cells in humans. In AKI patients, OPN is strongly upregulated and demonstrates both its role as a marker of injury and its relationship with outcome and severity (84).

$\pi$-Glutathione S-transferase ( $\pi$-GST) is a cytosolic enzyme that catalyzes the conjugation of glutathione for transport out of the cell. It acts a main role in keeping of cells from oncogenic and cytotoxic agents (85). The 35th week of pregnancy is important for the localization of $\pi$-GST. Until this time, it has been found in the proximal tubules and Bowman capsule, after that time it is expressed in the distal tubule and collecting tubules (86). Therefore, $\pi$-GST is released from damaged proximal tubules in preterm newborns and released from damaged distal tubules in adults and older children. $\pi$-GST is released in urine in kidney injury which is expressed a early marker of tubular injury (87). In several studies urinary GST has assessed as a biomarker of AKI in children and adults. Also, $\pi$-GST could be a significant factor for early diagnosis of severe AKI (88).

Calbindin is a cytosolic vitamin-D-dependent calcium binding protein. It exists in several cells and tissues such as peripheral and central nervous systems, enteric neuroendocrine cells (89), distal tubular cells and proximal part of collecting duct in kidney (90). Calbindin is considered a biomarker in the prediction of kidney injury, as it is released from the distal tubule of the injured kidney where $\mathrm{Ca}^{+2}$ reabsorption is involved (91). After renal injury, urinary calbindin concentrations increase rapidly peaked at 6 hours and it return to baseline values by 24 hours (92).

Calprotectin is an antimicrobial protein that originates from neutrophils and monocytes. It is produced by epithelial cells of collecting duct in kidney. Calprotectin consists of two units: S100A8 and S100A9. They are activators of toll-like receptor 4 (TLR4) which mediates innate immunity by calprotectin (93). Calprotectin and TLR4 amplify the inflammatory cascade and calprotectin acts as a damage-associated molecular pattern protein. This characteristic role has been observed in the pathophysiology of various diseases even in the cellular mechanism of AKI, innate immunity is activated by TLR4 (94). Chang et al (94) also reported that urine calprotectin is highly useful for diagnosis of AKI. Urinary calprotectin is also important in discrimination of intrinsic and prerenal AKI. Consequently, calprotectin displays in higher levels in intrinsic AKI than prerenal AKI makes it valuable marker in the differential diagnosis of AKI both in pediatric and adult patients $(93,95)$.

Trefoil factor (TFF)-3 is a small (13.1 kD) peptide that is a member of the trefoil factor family. It is expressed by epithelial cells within gastrointestinal tract (especially goblet cells of the intesine and colon) and the kidneys. In the kidney, TFF-3 is produced by cells of cortical collecting ducts and proximal and distal tubules. It plays a main role in the repair and protection of epithelial cells and tubular regeneration early after kidney injury (96). Urinary levels of TFF-3 is correlated with renal function after AKI (97). As a result, TFF3 is part of the kidney's regenerative defense and has also been recognized as a biomarker of acute and chronic kidney injury (89).

Galectin-3 (GAL-3) is a protein from the leptin family that binds to $\beta$-galactosides. It is expressed in many tissues, including kidney. It has many functions in the kidney, such as regulating cell growth, proliferation, differentiation, and inflammatory response (98). Its expression in tubular inflammatory cells increases in response to acute damage to the kidneys (99). Therefore, it may be useful to determine acute inflammatory kidney damage.

Dickkopf-3 (DKK-3) is a glioprotein expressed from renal 
tubular epithelial cells and one of the regulators of the Wnt/ßcatenin pathway (100). Its secretion to urine increases with tubular stress. Although there is no decrease in GFR, its rise in urine indicates tubular stress (101). Therefore, it can predict AKI and kidney function loss in patients showing a GFR value within normal limits without albuminuria (102). DKK-3 makes AKI risk predictable.

C-C motif chemokine ligand 14 (CCL14, HCC-1) is members of the chemokine family. CCL-14 is an important chemokine in monocyte / macrophage recruitment. It takes part in tissue injury and repair processes. The release of inflammatory mediators after injury causes the release of CCL-14 from tubular epithelial cells. The released CCL-14 induces chemotaxis of monocytes to the injury site. As monocyte / macrophage recruitment causes kidney tissue damage and dysfunction (103), CCL-14 is thought to play a mediating role in AKI (104). The amount of CCL-14 secreted may indicate the degree of tissue damage. Urine CCL-14 level predicts AKI prognosis and can also be a therapeutic target in AKI (104).

Chitinase 3-like protein 1 (CHI3L1, YKL-40) is a low molecular weight (39 kDa) glycoprotein secreted from active macrophages, neutrophils and fibroblasts and various cell types in response to inflammation. It is also produced by tubular cells in healthy kidney tissue. It is freely filtered by glomeruli due to its low molecular weight. Its secretion from macrophages in the kidney increases after tubular damage or tubular stress $(105,106)$. CHI3L1 levels are associated with tubular injury and repair, inflammation, hemolysis, endothelial activation (107-109). Urinary CHI3L1 levels are associated with the severity of AKI and increased cystatin C, suggesting that it is a biomarker that can be used to diagnose AKI (108-111).

\section{BIOMARKERS WITH UNKNOWN SPECIFIC RENAL SITE}

Hepcidin-25 are iron-retaining antimicrobial proteins that regulate the circulating iron by breaking down the iron carrier ferroportin (112). Although the origin of urinary hepcidin-25 is unknown, it undergoes glomerular filtration and is partially absorbed from the proximal tubules (113). After renal ischemia reperfusion injury, hepcidin-25 increase is observed to regulate ferroportin regulation to alleviate the effects of circulating iron release. This increase is thought to be a renoprotective response to reduce kidney damage (114-116). The combined use of Hepcidin-25 with other biomarkers may ease detection of the newly started AKI (117).

Beta-trace protein (BTP) is a protein from the lipocalin family known as prostaglandin D2 synthase. It is synthesized in many organs including kidney, especially central nervous system glial cells. Since it has low molecular weight and does not bind to plasma proteins, it is freely filtered by the glomerulus and reabsorbed by the proximal tubule (118). BTP, seen as the determinant of GFR, can be used to predict AKI, but its diagnostic accuracy is lower than serum cystatin $\mathrm{C}$ or serum and urine NGAL (119-121).

Proenkefalin (PENK) is an endogenous opioid polypeptide hormone expressed in many tissues, including the kidney (122). It is a biomarker that shows kidney function (not damage) closely related to $\operatorname{GFR}(123,124)$. It is a predictor of the development of AKI because it increases before $\mathrm{SCr}$ (125).

\section{BIOMARKERS WITH NON-RENAL ORIGIN}

Albumin is a high molecular weight protein $(66.5 \mathrm{kD})$ that is rarely detected in the urine due to its filtration barrier and its reabsorption in the proximal tubules. Albumin can be seen in the urine when there is glomerular and/or tubular kidney injury (126). However, serum albumin is a negative acute phase protein in acute inflammation that associated with decreased albumin synthesis and increased catabolism that has also been associated with AKI (127). Normally, albumin is silent in the kidney but it can be induced by AKI and after that renal cortical mRNA expression increases. Albumin has been used as a biomarker in both glomerular and tubular injury. As an indicator of glomeruler injury, abnormal change of urine albumin can further damage the nephron tissue (128). On the other hand in acute tubular injury, urinary albumin has been shown to be superior to urea and $\operatorname{SCr}(129,130)$. As a result, albumin is used as a biomarker in the early diagnosis of AKI and has many advantages such as using clinical routine, commercial availability and cost-effective (129).

Ischemia Modified Albumin (IMA) occurs as a result of the production of reactive oxygen species after ischemia. It is the form of albumin formed by impaired ability to bind to certain metal ions such as copper and nickel, especially cobalt. It is a nonspecific biomarker that can be measured in a short time after ischemic injury (131). Studies have been shown to be used after renal ischemic injury $(132,133)$. Although not alone, it can be used with other biomarkers in the diagnosis of AKI.

Alpha1 microglobulin (a1-MG) is a low molecular weight protein that is synthetized in liver, freely filtered by the glomerulus and almost completely reabsorbed by the proximal tubular cells. Lower levels of $\alpha 1-\mathrm{MG}$ is associated with preserved tubular reabsorptive capacity (134). In the presence of proximal tubule cell dysfunction, renal absorption decreases, 
and urinary excretion increases so, in the urine, $\alpha 1-\mathrm{MG}$ concentration is elevated. Higher $\alpha 1-\mathrm{MG}$ has been found to be a greater risk factor for AKI, regardless of GFR, albumin concentration, other risk factors, and markers of tubular cell injury. As a result, $\alpha 1-\mathrm{MG}$ is cost-effective and valuable biomarker for the early diagnosis of AKI $(135,136)$.

$\boldsymbol{\beta}$-microglobulin $\left(\boldsymbol{\beta}_{2}-\mathbf{M G}\right)$ is low molecular weight protein that exists in all nucleated cells. Because of its low molecular weight, $\beta_{2}-\mathrm{MG}$ is freely filtered by the glomerulus, and completely reabsorbed and catabolized in the renal tubules. Urinary $\beta_{2}-\mathrm{MG}$ concentration elevates when the renal tubular damage or AKI $(135,137)$. These properties can make an ideal endogenous biomarker to estimate the glomerular filtration rate. Many studies have found that $\beta_{2}-\mathrm{MG}$ is a useful and early predictor of AKI in liver transplant patients and kidney allograft patients (138). Barton et al also showed that urine and serum $\beta_{2}$-MG correlates with severity of AKI (139). Therefore, $\beta_{2}-\mathrm{MG}$ can be used more frequently as it has relatively low cost and wider clinical availability compared to other biomarkers (139).

Cystatin $C$ is a cysteine protease inhibitory protein produced by all nucleated cells. Due to its low molecular weight (13.3 $\mathrm{kD}$ ), it is freely filtered by the glomeruli and is fully absorbed by the proximal tubules and catabolized; however, it is not secreted from tubules. Therefore, detection of cystatin $\mathrm{C}$ in urine indicates tubular dysfunction (34). Although serum cystatin C is a functional marker of GFR, it is not affected by extrarenal factors such as diet, sex, age, muscle mass, or tubular secretion; its concentration is almost entirely dependent on GFR $(140,141)$. Serum cystatin C increases 24-48 hours after AKI, this increase is prior to $\mathrm{SCr}(142,143)$. Therefore, in the early diagnosis of AKI, it is more sensitive and specific than $\mathrm{SCr}$ affected by non-renal factors $(24,144)$.

RBP (retinol binding protein) is a low molecular weight protein that is synthesized in the liver and is responsible for carrying vitamin A from the liver to other tissues. It is freely filtered in the glomerulus and almost completely absorbed from the proximal tubule. Therefore, sensitive indication of tubular damage is accepted. Although its sensitivity is lower than $\beta_{2} \mathrm{M}$, it is higher than NAG (26). Detection of RBP in urine without microalbuminuria and without decreasing GFR is an important biomarker for early detection of tubular damage $(145,146)$.

Hepatocyte growth factor (HGF) plays a role in tubular cell proliferation. HGF causes mitosis in tubular cells through the C - Met receptor tyrosine kinase (147). Tubular cell apoptosis is facilitated by downregulating fibroblast HGF expression (e.g. by activating fibroblast $\beta$-catenin signal), blocking tubular cell c-met signaling or mTOR signal in kidney fibroblasts $(148,149)$. Although it is not expressed in proximal renal cells, HGF gene expression increases at the onset of AKI and expression decreases with the recovery phase (150). With this upregulation, it protects tubular cells against death and plays an important role in alleviating kidney dysfunction after AKI. Therefore, it has a renoprotective role in AKI and can be used in the early diagnosis of AKI (151).

Chemokine C-C ligand-2 (CCL-2; Monocyte chemotactic protein-1 [MCP-1]) is a member of the chemokine family. CCL-2 is responsible for monocyte recruitment in acute inflammation, recruits them to inflammatory sites and regulates inflammation through the production of proinflammatory cytokines $(152,153)$. It is also a chemotactic cytokine that supports adhesion in the vascular endothelium and releases growth factors (23). CCL-2, which plays an important role in the proinflammatory response, is associated with glomerular filtration, glomerular lesion and renal perfusion $(154,155)$. Since increased plasma CCL-2 levels show high AKI risk, it may be a biomarker that can be used to identify high-risk patients for potential AKI (156-158).

\section{INTERIM SUMMARY}

In the section up to now, biomarkers that can be used in the early diagnosis of AKI are classsified according to their anatomical origin, i.e. tubular, glomerular, unknown site of kidney (Table 1). In addition, biomarkers according to the biological materials from where they can be detected (urine, blood, kidney tissue) are shown in Table 2. In next section, the management of AKI and clinical use of biomarkers will be discussed.

\section{CLINICAL IMPORTANCE OF RENAL INJURY BIOMARKERS}

\section{Definition of AKI}

$\mathrm{AKI}$ is a multifactorial complex disease with different clinical manifestations, from a minimal rise in SCr to anuric kidney failure (159). AKI occurs in $10-20 \%$ of hospitalized patients, and $10 \%$ of them require kidney replacement therapy (RRT). This rate rises to $50 \%$ in intensive care units. In the USA, AKI caused high hospitalization costs ranging from $\$ 5.4$ to $\$ 24.0$ billion (160). The total mortality rate can reach up to $24 \%$ on the 30th day after AKI.

Three AKI definitions are used frequently:

- RIFLE, $\mathrm{SCr}>50 \%$ increase from baseline, and/or urine volume $<0.5 \mathrm{ml} / \mathrm{kg} / \mathrm{h}$ for $6 \mathrm{~h}$. 
Table 1. Acute kidney injury markers

\begin{tabular}{|l|l|l|l|}
\hline Renal origin & & & $\begin{array}{l}\text { Non-renal } \\
\text { origin }\end{array}$ \\
\hline Tubular & & Glomerular & \\
\hline KIM-1 & NGAL & suPAR & Albumin \\
\hline L-FABP & Clusterin & & IMA \\
\hline NAG & Uromodulin & Unknown & a1- MG \\
\hline NephroCheck & OPN & Hepcidin-25 & B2- MG \\
\hline a -GST & T-GST & BTP & Cystatin C \\
\hline IL-18 & Calbindin & PENK & RBP \\
\hline NHERF-1 & Calprotectin & & HGF \\
\hline Netrin-1 & TFF-3 & & CCL-2 \\
\hline MMP-7 & GAL-3 & & \\
\hline MK & DKK-3 & & \\
\hline miRNAs & CCL-14 & & \\
\hline AGT & CHI3L1 & & \\
\hline NHE-3 & & & \\
\hline
\end{tabular}

Table 2. Sampling for measurements of biomarkers

\begin{tabular}{|l|l|l|l|}
\hline Urine & & Plasma & Urine\&Plasma \\
\hline L-FABP & OPN & suPAR & KIM-1 \\
\hline NAG & $\pi$-GST & BTP & miRNAs \\
\hline NephroCheck & Calbindin & GAL-3 & Albumin \\
\hline a-GST & Calprotectin & PENK & \\
\hline IL-18 & TFF-3 & IMA & Kidney Tissue \\
\hline NHERF-1 & DKK-3 & Cystatin C & miRNAs \\
\hline Netrin-1 & CCL-14 & CCL-2 & \\
\hline MMP-7 & CHI3L1 & & \\
\hline MK & Hepcidin-25 & & \\
\hline AGT & a1- MG & & \\
\hline NHE-3 & B2- MG & & \\
\hline NGAL & RBP & & \\
\hline Clusterin & HGF & & \\
\hline Uromodulin & & & \\
\hline
\end{tabular}

- $\quad$ AKIN, $\mathrm{SCr}>50 \%$ increase or by $0.3 \mathrm{mg} / \mathrm{dl}$ from baseline in $48 \mathrm{~h}$, and/or urine volume $<0.5 \mathrm{ml} / \mathrm{kg} / \mathrm{h}$ for $6 \mathrm{~h}$.

- $\mathrm{KDIGO}, \mathrm{SCr}>50 \%$ increase within the prior $7 \mathrm{~d}$ or by $0.3 \mathrm{mg} / \mathrm{dl}$ from baseline in $48 \mathrm{~h}$, and/or urine volume $<0.5 \mathrm{ml} / \mathrm{kg} / \mathrm{h}$ for $6 \mathrm{~h}$.

$\mathrm{SCr}$ is a low sensitive and specific for AKI since it occurs up to 48-72 hours from damage. It stays up normal to less than $50 \%$ of the reduction in healthy nephrons, misses subclinical damage and is not diagnostic among prerenal, parenchymal, and obstructive nephropathy. There are also problems in measuring baseline SCr. The Acute Dialysis Quality Initiative (ADQI) recommended the 'modification of diet in renal disease' (MDRD) formula for patients without existing baseline $\mathrm{SCr}$; Provides a strong GFR prediction based on SCr by age, race and gender. European Renal Best Practice (ERBP) suggested that the SCr value at the first admission to the hospital should be accepted to the baseline (161). Considering that age-related GFR decrease, perioperative and intensive care patients may have an excessive volume load and SCr levels may be increased before hospital admission, the reliability of these measurements decreases.

\section{ETIOLOGY}

Glomerular filtration consists of the pressure difference between the bowman capsule and the glomerule. This pressure is under the control of renal blood flow, the resistance of afferent and efferent vessels. In general, AKI occurs due to a decrease in renal blood flow. It is examined in 3 main groups as prerenal, renal and postrenal.

Prerenal AKI occurs because of a decrease in kidney blood flow due to any reason. Bleeding, nausea, vomiting, cardiogenic shock, acute coronary syndrome, septic shock, anaphylaxis, hepatorenal syndrome, and anesthesia administration may lead to prerenal AKI due to hypovolemia and hypotension. NSAID, hepatorenal syndrome and ionized contrast; they cause prerenal AKI by renal vasoconstriction. Also, angiotensin receptor blockers and ACE inhibitors may cause AKI by vasodilation in efferent arterioles.

Renal AKI is caused by the release of vasoconstrictors from afferent arteriole due to glomerule and tubule injuries. Prolonged renal ischemia, intravascular hemolysis, rhabdomyolysis and aminoglycosides can cause renal AKI by leading acute tubular necrosis (ATN). Infections, autoimmune reactions, beta-lactam antibiotics, penicillin and NSAIDs can cause acute interstitial nephritis and renal AKI. Autoimmune diseases and vasculitis leading to glomerulonephritis and intratubular 
obstruction are also the cause of renal AKI.

Postrenal AKI occurs because of a change in glomerular filtration pressure due to partial or complete blockage in the urinary passage for any reason. The most common causes include ureter-kidney stones, bladder outlet obstruction, tumor compression to the ureter and blood clot. AKI clinic may not always be seen due to the compensatory effect of the contralateral kidney in unilateral ureteral obstruction.

\section{RISK FACTORS}

Older age, DM, HT, sepsis, anemia, high-risk surgery, peripheral vascular diseases, nephrotoxic drug use, heart failure, hemodynamic instability, and CKD are factors that increase the risk for AKI. Scoring systems have been developed to identify high-risk patients before surgery Cleveland Clinic score, Mehta score, and Simplified Renal Index (SRI) score are the most frequently used for cardiac operations (162). Also, clinical studies have been conducted for some predictive biomarkers. suPAR, PENK, CCL-2, hepcidin-25, GAL-3, uromodulin gave promising results $(12,117,163,164)$. The researchers think that these predictive biomarkers will be integrated into the scoring systems so that more specific results will be obtained.

\section{MANAGEMENT OF AKI}

The most important step in AKI patients is to identify the underlying cause and understand its etiology. In the first plan, the fluid taken and urine extracted should be monitored, blood parameters should be checked; hypo-hyperkalemia, acidosis and other electrolyte imbalances should be examined. All nephrotoxic drugs such as NSAID, ACE / ARB inhibitor, ionized contrast should be avoided. Fluid replacement should be initiated and hypotension should be avoided. If necessary, a vasopressor can be used. Prerenal AKI generally responds very well to fluid replacement therapy. Renal AKI is resistant and the clinic may take months to recover. There is no effective pharmacotherapy for ATN treatment leading to renal AKI (161). Immunosuppressive drugs can be used for autoimmune causes. Elimination of the obstruction that causes postrenal AKI is sufficient for treatment. In all these diagnostic and treatment processes, dialysis can be performed to prevent acute AKI complications. Hyperkalemia, acidosis, anuria, uremic pericarditis and pulmonary edema that do not respond to treatment are indications for dialysis.

\section{LONG TERM EFFECTS OF AKI}

Patients who have survived the AKI episode; face increased risk of death, cardiovascular event, hypertension, $\mathrm{CKD}$, stroke and decreased quality of life in the long term. Advanced age and comorbid diseases increase the rate of these effects (165). Patients should be checked for 3-6 month periods due to possible complications and risk of CKD. Keeping blood glucose and blood pressure at normal values, regulating weight control and fluid intake, minimizing proteinuria and avoiding nephrotoxic drugs are methods that reduce possible long-term complications.

\section{CLINICAL USAGE OF BIOMARKERS}

$\mathrm{AKI}$ is an important complication that increases mortality and morbidity for clinical applications AKI increases perioperative morbidity, as well as postoperative mortality, complications, length of hospital stay, and increased hospital costs (166).

The three classifications created for AKI criteria and diagnosis are based on the increase in $\mathrm{SCr}$ levels and a decrease in urine output on a weight basis. However, it is known that $\mathrm{SCr}$ level is affected by age and muscle mass and rises in the late period. Also, differences in urine measurement method prevent these classifications from being made healthy (167). Therefore, the need to develop new biomarkers for predicting and diagnosing AKI among high-risk patients is very obvious. An AKI patient subgroup was identified that did not meet the functional criteria used conventionally for the diagnosis of AKI, but exhibits high levels of new biomarkers that probably reflect tubular damage, and these patients were diagnosed as "subclinical AKI" (168). Biomarkers that rise within a few hours after the occurrence of tubular damage and give early warning in the diagnosis and progression of AKI include NGAL, KIM-1, L-FABP, IL-18, NefroCheck, Calprotectin, AGT, miRNAs, NAG, uMMP-7, GST, uMMP-7, Netrin-1, MK (Table 3). In addition, it has been determined that some biomarkers examined before the procedure may predict the risk of AKI. Some of these predictive biomarkers are: suPAR, PENK, CCL-2, hepcidin-25, GAL-3, uromodulin.

These biomarkers with multifactorial biochemical activities have different limitations. First of all, biomarkers have specific patient groups and no fixed cut-off values. NGAL is one of the most studied biomarkers and has given promising results for diagnosis and prognosis in studies conducted in various patient groups. Increased levels of bacterial infection and sepsis, which are common in the AKI patient group, were determined (169). Another important biomarker in diagnosis and prognosis, KIM-1, has been found to be increased with proteinuria, which is common in the AKI patient group (170). 
L-FABP was found to be elevated with anemia in nondiabetic patients (171). The effectiveness of IL-18 in AKI prediction in adults is controversial. It was observed that NefroCheck levels increased with chronic diseases and DM. Increased levels of calprotectin in urinary infections, urinary malignancies and inflammatory diseases have been determined (172).

Table 3. Clinical usage of biomarkers

\begin{tabular}{|c|c|c|}
\hline & Diagnostic & Prognostic \\
\hline KIM-1 & $\begin{array}{l}\text { Nephrotoxic drugs } \\
\text { Cardiac Surgery } \\
\text { ICU }\end{array}$ & $\begin{array}{l}\text { Nephrotoxic } \\
\text { drugs } \\
\text { ICU }\end{array}$ \\
\hline L-FABP & $\begin{array}{l}\text { Emergency department } \\
\text { Nephrotoxic drugs } \\
\text { ICU } \\
\text { Cardiac Surgery }\end{array}$ & $\begin{array}{l}\text { ICU } \\
\text { Cardiac Surgery }\end{array}$ \\
\hline NAG & $\begin{array}{l}\text { ICU } \\
\text { Emergency department }\end{array}$ & $\begin{array}{l}\text { Emergency } \\
\text { department }\end{array}$ \\
\hline NephroCheck & $\begin{array}{l}\text { ICU } \\
\text { Coronary bypass } \\
\text { Major Surgery } \\
\text { Cardiac Surgery }\end{array}$ & ICU \\
\hline GST & ICU & \\
\hline IL-18 & $\begin{array}{l}\text { Emergency department } \\
\text { Pediatric Cardiac Surgery } \\
\text { ICU } \\
\text { Kidney Transplant } \\
\text { Recipients }\end{array}$ & $\begin{array}{l}\text { ICU } \\
\text { Cardiac Surgery } \\
\text { Acute } \\
\text { cardiorenal } \\
\text { syndrome }\end{array}$ \\
\hline Netrin-1 & Liver transplantation & \\
\hline uMMP-7 & Cardiac Surgery & Cardiac Surgery \\
\hline MK & $\begin{array}{l}\text { Cardiac Surgery } \\
\text { Nephrotoxic drugs }\end{array}$ & \\
\hline miRNAs & Cardiac Surgery & $\begin{array}{l}\text { ICU } \\
\text { Cardiac Surgery }\end{array}$ \\
\hline AGT & $\begin{array}{l}\text { Acute decompensated } \\
\text { heart failure }\end{array}$ & $\begin{array}{l}\text { Acute } \\
\text { cardiorenal } \\
\text { syndrome }\end{array}$ \\
\hline NGAL & $\begin{array}{l}\text { Nephrotoxic drugs } \\
\text { Cardiac Surgery } \\
\text { Preeclampsia } \\
\text { Liver-Kidney Transplant } \\
\text { Recipients }\end{array}$ & $\begin{array}{l}\text { Nephrotoxic } \\
\text { drugs } \\
\text { Cardiac Surgery } \\
\text { ICU } \\
\text { Acute } \\
\text { cardiorenal } \\
\text { syndrome }\end{array}$ \\
\hline Calprotectin & $\begin{array}{l}\text { All hospitalized patients } \\
\text { ICU } \\
\text { Cardiac Surgery }\end{array}$ & \\
\hline Cystatin C & Cardiac Surgery & Cardiac Surgery \\
\hline
\end{tabular}

\section{CONCLUSION}

Although there are biomarkers approved in some countries, their use could not be universal due to difficulties in their clinical uses, cost effective properties and widespread limitations. In order to increase the diagnostic value, most researchers think that biomarker combinations would be more appropriate. Before suggesting new biomarkers for acute kidney injury, we need to organize the existing ones in more useful manner to support clinicians who need a timely diagnosis and management of this clinical condition.

\section{CONFLICT OF INTEREST}

All authors declare no conflict of interest.

\section{ACKNOWLEDGEMENTS}

We are indebted to Professor Levent Öztürk for his valuable suggestions and review of the final version of this manuscript.

\section{REFERENCES}

1. James MT, Bhatt M, Pannu N, Tonelli M. Long-term outcomes of acute kidney injury and strategies for improved care. Nat Rev Nephrol 2020; 16(4):193-205. DOI:10.1038/s41581-019-0247-z.

2. Ostermann M, Cerdá J. The burden of acute kidney injury and related financial issues. Contrib Nephrol 2018; 193:100-112. DOI:10.1159/000484967.

3. Hoste EAJ, Kellum JA, Selby NM, Zarbock A, Palevsky PM, Bagshaw SM, et al. Global epidemiology and outcomes of acute kidney injury. Nat Rev Nephrol 2018; 14(10):607-625. DOI: 10.1038/s41581-018-0052-0.

4. Ostermann M, Joannidis M. Acute kidney injury 2016: diagnosis and diagnostic workup. Crit Care 2016; 20(1):299. DOI:10.1186/s13054-016-1478-z.

5. Roy JP, Devarajan P. Acute kidney injury: diagnosis and management. Indian J Pediatr 2020; 87(8):600-607. DOI:10.1007/s12098-019-03096-y.

6. Hayek SS, Leaf DE, Reiser J. Soluble urokinase receptor and acute kidney injury. Reply. N Engl J Med 2020; 382(22):2167-2168. DOI:10.1056/NEJMc2003613.

7. Eugen-Olsen J, Andersen O, Linneberg A, Ladelund S, Hansen TW, Langkilde A, et al. Circulating soluble urokinase plasminogen activator receptor predicts cancer, cardiovascular disease, diabetes and mortality in the general population. J Intern Med 2010; 268(3):296-308. DOI:10.1111/j.1365-2796.2010.02252.x.

8. Backes Y, van der Sluijs KF, Mackie DP, Tacke F, Koch 
A, Tenhunen JJ, et al. Usefulness of suPAR as a biological marker in patients with systemic inflammation or infection: a systematic review. Intensive Care Med 2012; 38(9):1418-1428. DOI: 10.1007/s00134-012-2613-1.

9. Hahm E, Wei C, Fernandez I, Li J, Tardi NJ, Tracy M, et al. Bone marrow-derived immature myeloid cells are a main source of circulating suPAR contributing to proteinuric kidney disease. Nat Med 2017; 23(1):100-106. DOI:10.1038/nm.4242.

10. Hayek SS, Koh KH, Grams ME, Wei C, Ko YA, Li J, et al. A tripartite complex of suPAR, APOL1 risk variants and $\alpha v \beta 3$ integrin on podocytes mediates chronic kidney disease. Nat Med 2017; 23(8):945-953. DOI:10.1038/ nm.4362.

11. Wei C, Li J, Adair BD, Zhu K, Cai J, Merchant M, et al. uPAR isoform 2 forms a dimer and induces severe kidney disease in mice. J Clin Invest 2019; 129(5):1946-1959. DOI:10.1172/JCI124793.

12. Faubel S. SuPAR: a potential predictive biomarker for acute kidney injury. Nat Rev Nephrol 2020; 16(7):375376. DOI:10.1038/s41581-020-0276-7.

13. Hall A, Crichton S, Varrier M, Bear DE, Ostermann M. suPAR as a marker of infection in acute kidney injury a prospective observational study. BMC Nephrol 2018; 19(1):191. DOI:10.1186/s12882-018-0990-6.

14. Moresco RN, Bochi GV, Stein CS, De Carvalho JAM, Cembranel BM, Bollick YS. Urinary kidney injury molecule-1 in renal disease. Clin Chim Acta 2018; 487:1521. DOI: 10.1016/j.cca.2018.09.011.

15. Koyner JL, Vaidya VS, Bennett MR, Ma Q, Worcester $\mathrm{E}$, Akhter SA, et al. Urinary biomarkers in the clinical prognosis and early detection of acute kidney injury. Clin J Am Soc Nephrol 2010; 5(12):2154-2165. DOI:10.2215/ CJN.00740110.

16. Parikh CR, Thiessen-Philbrook H, Garg AX, Kadiyala D, Shlipak MG, Koyner JL, et al. Performance of kidney injury molecule- 1 and liver fatty acid-binding protein and combined biomarkers of AKI after cardiac surgery. Clin J Am Soc Nephrol 2013; 8(7):1079-1088. DOI:10.2215/ CJN.10971012.

17. Huang Y, Don-Wauchope AC. The clinical utility of kidney injury molecule 1 in the prediction, diagnosis and prognosis of acute kidney injury: a systematic review. Inflamm Allergy Drug Targets 2011; 10(4):260271. DOI:10.2174/187152811796117735.

18. Ismail OZ, Zhang X, Wei J, Haig A, Denker BM, Suri
RS, et al. Kidney injury molecule-1 protects against Ga12 activation and tissue damage in renal ischemiareperfusion injury. Am J Pathol 2015; 185(5):1207-1215. DOI: 10.1016/j.ajpath.2015.02.003.

19. Ahmed SA, Hamed MA. Kidney injury molecule-1 as a predicting factor for inflamed kidney, diabetic and diabetic nephropathy Egyptian patients. J Diabetes Metab Disord 2015; 14:6. DOI:10.1186/s40200-015-0131-8.

20. Xu Y, Xie Y, Shao X, Ni Z, Mou S. L-FABP: A novel biomarker of kidney disease. Clin Chim Acta 2015; 445:85-90. DOI:10.1016/j.cca.2015.03.017.

21. Kashani K, Cheungpasitporn W, Ronco C. Biomarkers of acute kidney injury: the pathway from discovery to clinical adoption. Clin Chem Lab Med 2017; 55(8):10741089. DOI:10.1515/cclm-2016-0973.

22. Teo SH, Endre ZH. Biomarkers in acute kidney injury (AKI). Best Pract Res Clin Anaesthesiol 2017; 31(3):331-344. DOI:10.1016/j.bpa.2017.10.003.

23. Luft FC.(2020) Biomarkers and predicting acute kidney injury. Acta Physiol (Oxf) e13479. DOI:10.1111/ apha.13479.

24. Griffin BR, Faubel S, Edelstein CL. Biomarkers of drug-induced kidney toxicity. Ther Drug Monit 2019; 41(2):213-226. DOI:10.1097/FTD.0000000000000589.

25. Omozee EB, Okaka EI, Edo AE, Obika LF. Urinary Nacetyl-betad-glucosaminidase levels in diabetic adults. J Lab Physicians 2019; 11:1-4. DOI:10.4103/JLP. JLP_164_17.

26. Andreucci M, Faga T, Pisani A, Perticone M, Michael A. The ischemic/nephrotoxic acute kidney injury and the use of renal biomarkers in clinical practice. Eur J Intern Med 2017; 39:1-8. DOI:10.1016/j.ejim.2016.12.001.

27. Srisawat N, Kellum JA. The role of biomarkers in acute kidney injury. Crit Care Clin 2020; 36(1):125-140. DOI:10.1016/j.ccc.2019.08.010.

28. Johnson ACM, Zager RA. Mechanisms underlying increased TIMP2 and IGFBP7 urinary excretion in experimental AKI. J Am Soc Nephrol 2018; 29(8): 2157-2167. DOI:10.1681/ASN.2018030265.

29. Kellum JA, Chawla LS. Cell-cycle arrest and acute kidney injury: the light and the dark sides. Nephrol Dial Transplant 2016; 31(1):16-22. DOI:10.1093/ndt/gfv130.

30. Kane-Gill SL, Peerapornratana S, Wong A, Murugan R, Groetzinger LM, Kim C, et al. Use of tissue inhibitor of metalloproteinase 2 and insulin-like growth factor binding protein 7 [TIMP2]•[IGFBP7] as an AKI risk 
screening tool to manage patients in the real-world setting. J Crit Care 2020; 57:97-101. DOI:10.1016/j. jcrc.2020.02.002.

31. Ostermann M, McCullough PA, Forni LG, Bagshaw SM, Joannidis M, Shi J, et al. Kinetics of urinary cell cycle arrest markers for acute kidney injury following exposure to potential renal insults. Crit Care Med 2018; 46(3):375-383. DOI:10.1097/CCM.0000000000002847.

32. Cho WY, Lim SY, Yang JH, Oh SW, Kim MG, Jo SK. Urinary tissue inhibitor of metalloproteinase-2 and insulin-like growth factor-binding protein 7 as biomarkers of patients with established acute kidney injury. Korean J Intern Med 2020; 35(3):662-671. DOI:10.3904/ kjim.2018.266

33. Won AJ, Kim S, Kim YG, Kim KB, Choi WS, Kacew $\mathrm{S}$, et al. Kim KS, Jung JH, Lee BM, Kim S, Kim HS. Discovery of urinary metabolomic biomarkers for early detection of acute kidney injury. Mol Biosyst 2016; 12(1):133-144. DOI:10.1039/c5mb00492f.

34. Edelstein CL. Biomarkers of acute kidney injury. Adv Chronic Kidney Dis 2008; 15(3):222-234. DOI:10.1053/j.ackd.2008.04.003.

35. Dobilienė D, Masalskienè J, Rudaitis Š, Vitkauskienė A, Pečiulytė J, Kèvalas R. Early diagnosis and prognostic value of acute kidney injury in critically Ill patients. $\mathrm{Me}$ dicina (Kaunas) 2019; 55(8):506. DOI:10.3390/medicina55080506.

36. Amaral Pedroso L, Nobre V, Dias Carneiro de Almeida C, da Silva Praxedes MF, Sernizon Guimarães N, Simões E Silva AC, et al. Parreiras Martins MA. Acute kidney injury biomarkers in the critically ill. Clin Chim Acta 2020; 508:170-178. DOI:10.1016/j.cca.2020.05.024.

37. Cunningham R, Biswas R, Steplock D, Shenolikar S, Weinman E. Role of NHERF and scaffolding proteins in proximal tubule transport. Urol Res 2010;38(4):257-262. DOI:10.1007/s00240-010-0294-1.

38. Khundmiri SJ, Weinman EJ, Steplock D, Cole J, Ahmad A, Baumann PD, et al. Parathyroid hormone regulation of $\mathrm{NA}+, \mathrm{K}+-\mathrm{ATPase}$ requires the PDZ 1 domain of sodium hydrogen exchanger regulatory factor-1 in opossum kidney cells. J Am Soc Nephrol 2005;16(9):2598-2607. DOI:10.1681/ASN.2004121049.

39. Bushau-Sprinkle A, Barati M, Conklin C, Dupre T, Gagnon KB, Khundmiri SJ, et al. Loss of the $\mathrm{Na}^{+}$/ $\mathrm{H}^{+}$Exchange Regulatory Factor 1 Increases Susceptibility to Cisplatin-Induced Acute Kidney Injury. Am
J Pathol 2019;189(6):1190-1200. DOI:10.1016/j.ajpath.2019.02.010.

40. Övünç Hacıhamdioğlu D, Hacıhamdioğlu B, Altun D, Müftüoğlu T, Karademir F, Süleymanoğlu S.Urinary netrin-1: a new biomarker for the early diagnosis of renal damage in obese children. J Clin Res Pediatr Endocrinol 2016;8(3):282-287. DOI:10.4274/jcrpe.2828.

41. Beker BM, Corleto MG, Fieiras C, Musso CG. Novel acute kidney injury biomarkers: their characteristics, utility and concerns. Int Urol Nephrol 2018;50(4):705713. DOI:10.1007/s11255-017-1781-x.

42. Parrish AR. Matrix Metalloproteinases in Kidney Disease: Role in Pathogenesis and Potential as a Therapeutic Target. Prog Mol Biol Transl Sci 2017;148:31-65. DOI:10.1016/bs.pmbts.2017.03.001.

43. Yang X, Chen C, Teng S, Fu X, Zha Y, Liu H, et al. Urinary Matrix Metalloproteinase-7 Predicts Severe AKI and Poor Outcomes after Cardiac Surgery. J Am Soc Nephrol 2017;28(11):3373-3382. DOI:10.1681/ ASN.2017020142.

44. Ke B, Fan C, Yang L, Fang X. Matrix Metalloproteinases-7 and Kidney Fibrosis [published correction appears in Front Physiol. 2017;28;8:192]. Front Physiol 2017;8:21. DOI:10.3389/fphys.2017.00021.

45. Zhou D, Tian Y, Sun L, Zhou L, Xiao L, Tan RJ, et al. Matrix Metalloproteinase-7 Is a Urinary Biomarker and Pathogenic Mediator of Kidney Fibrosis. J Am Soc Nephrol 2017;28(2):598-611. DOI:10.1681/ASN.2016030354 (2017).

46. Fu H, Zhou D, Zhu H, Liao J, Lin L, Hong X, et al. Matrix metalloproteinase-7 protects against acute kidney injury by priming renal tubules for survival and regeneration. Kidney Int 2019;95(5):1167-1180. DOI:10.1016/j. kint.2018.11.043.

47. Fang F, Luo W, Yang M, Yang P, Yang X. Urinary Matrix Metalloproteinase-7 and Prediction of AKI Progression Post Cardiac Surgery. Dis Markers 2019;19;2019:9217571. DOI:10.1155/2019/9217571.

48. Liang J, Lin G, Tian J, Chen J, Liang R, Chen Z, et al. Measurement of urinary matrix metalloproteinase-7 for early diagnosis of acute kidney injury based on an ultrasensitive immunomagnetic microparticle-based time-resolved fluoroimmunoassay. Clin Chim Acta 2019;490:55-62. DOI:10.1016/j.cca.2018.11.037.

49. Kadomatsu K, Muramatsu T. Midkine and pleiotrophin in neural development and cancer. Cancer 
Lett 2004;204(2):127-143. DOI:10.1016/S03043835(03)00450-6.

50. Hayashi H, Sato W, Kosugi T, Nishimura K, Sugiyama $\mathrm{D}$, Asano $\mathrm{N}$, et al. Efficacy of urinary midkine as a biomarker in patients with acute kidney injury. Clin Exp Nephrol 2017;21(4):597-607. DOI:10.1007/s10157-0161318-0.

51. Sato W, Sato Y. Midkine in nephrogenesis, hypertension and kidney diseases. Br J Pharmacol 2014;171(4):879887. DOI:10.1111/bph.12418.

52. Kosugi T, Sato W. Midkine and the kidney: health and diseases. Nephrol Dial Transplant 2012;27(1):16-21. DOI:10.1093/ndt/gfr652.

53. McBride WT, Kurth MJ, McLean G, Domanska A, Lamont JV, Maguire D, et al. Stratifying risk of acute kidney injury in pre and post cardiac surgery patients using a novel biomarker-based algorithm and clinical risk score. Sci Rep 2019;9(1):16963. DOI:10.1038/ s41598-019-53349-1.

54. Albert C, Albert A, Kube J, Bellomo R, Wettersten $\mathrm{N}$, Kuppe $\mathrm{H}$, et al. Urinary biomarkers may provide prognostic information for subclinical acute kidney injury after cardiac surgery. $J$ Thorac Cardiovasc Surg 2018;155(6):2441-2452.e13. DOI:10.1016/j. jtcvs.2017.12.056.

55. Zou YF, Zhang W. Role of microRNA in the detection, progression, and intervention of acute kidney injury. Exp Biol Med (Maywood) 2018;243(2):129-136. DOI:10.1177/1535370217749472.

56. Bai H, Wu S. miR-451: A Novel Biomarker and Potential Therapeutic Target for Cancer. Onco Targets Ther 2019;12:11069-11082. DOI:10.2147/OTT.S230963.

57. Kumari M, Mohan A, Ecelbarger CM, Gupta A, Prasad N, Tiwari S. miR-451 loaded exosomes are released by the renal cells in response to injury and associated with reduced kidney function in human. Front. Physiol 2020;11:234. DOI:10.3389/fphys.2020.00234.

58. Du J, Cao X, Zou L, Chen Y, Guo J, Chen Z, et al. MicroRNA-21 and risk of severe acute kidney injury and poor outcomes after adult cardiac surgery. PLoS One 2013;8(5):e63390. DOI:10.1371/journal.pone.0063390.

59. Pavkovic M, Robinson-Cohen C, Chua AS, Nicoara O, Cárdenas-González M, Bijol V, et al. Detection of drug-induced acute kidney injury in humans using urinary KIM-1, miR-21, -200c, and -423. Toxicol Sci 2016;152(1):205-213. DOI:10.1093/toxsci/kfw077.
60. Zhang W, Zhou X, Zhang H, Yao Q, Liu Y, Dong Z. Extracellular vesicles in diagnosis and therapy of kidney diseases. Am J Physiol Renal Physiol 2016;311(5):F844F851. DOI:10.1152/ajprenal.00429.2016.

61. Cui S, Wu L, Feng X, Su H, Zhou Z, Luo W, et al. Urinary angiotensinogen predicts progressive chronic kidney disease after an episode of experimental acute kidney injury. Clin Sci (Lond) 2018;132(19):2121-2133. DOI:10.1042/CS20180758.

62. Kobori H, Nangaku M, Navar LG, Nishiyama A. The intrarenal renin-angiotensin system: from physiology to the pathobiology of hypertension and kidney disease. Pharmacol Rev 2007;59:251-287. DOI:10.1124/ pr.59.3.3.

63. Nakano D, Kobori H, Burford JL, Gevorgyan H, Seidel $\mathrm{S}$, Hitomi $\mathrm{H}$, et al. Multiphoton imaging of the glomerular permeability of angiotensinogen. $\mathrm{J} \mathrm{Am}$ Soc Nephrol 2012;23(11):1847-1856. DOI:10.1681/ ASN.2012010078.

64. Cao W, Jin L, Zhou Z, Yang M, Wu C, Wu L, et al. Overexpression of intrarenal renin-angiotensin system in human acute tubular necrosis. Kidney Blood Press Res 2016;41(6):746-756. DOI:10.1159/000450564.

65. Yang X, Chen C, Tian J, Zha Y, Xiong Y, Sun Z, et al. Urinary angiotensinogen level predicts AKI in acute decompensated heart failure: a prospective, two-stage study. J Am Soc Nephrol 2015;26(8):2032-2041. DOI:10.1681/ASN.2014040408.

66. Chen C, Yang X, Lei Y, Zha Y, Liu H, Ma C, et al. Urinary biomarkers at the time of AKI diagnosis as predictors of progression of AKI among patients with acute cardiorenal syndrome. Clin J Am Soc Nephrol 2016;11(9):1536-1544. DOI:10.2215/CJN.00910116.

67. Meisner A, Kerr KF, Thiessen-Philbrook H, Coca SG, Parikh CR. Methodological issues in current practice may lead to bias in the development of biomarker combinations for predicting acute kidney injury. Kidney Int 2016;89(2):429-438. DOI:10.1038/ki.2015.283.

68. Adiyanti SS, Loho T. Acute Kidney Injury (AKI) biomarker. Acta Med Indones 2012;44(3):246-255.

69. du Cheyron D, Daubin C, Poggioli J, Ramakers M, Houillier $\mathrm{P}$, Charbonneau $\mathrm{P}$, et al. Urinary measurement of $\mathrm{Na}+/ \mathrm{H}+$ exchanger isoform 3 (NHE3) protein as new marker of tubule injury in critically ill patients with ARF. Am J Kidney Dis 2003;42(3):497-506. DOI:10.1016/ s0272-6386(03)00744-3. 
70. Bagshaw SM, Langenberg C, Haase M, Wan L, May $\mathrm{CN}$, Bellomo R. Urinary biomarkers in septic acute kidney injury. Intensive Care Med 2007;33(7):1285-1296. DOI:10.1007/s00134-007-0656-5.

71. Oncel MY, Canpolat FE, Arayici S, Alyamac Dizdar E, Uras N, Oguz SS. Urinary markers of acute kidney injury in newborns with perinatal asphyxia. Ren Fail 2016;38(6):882-888. DOI:10.3109/088602 2X.2016.1165070.

72. Schmidt-Ott KM, Mori K, Kalandadze A, Li JY, Paragas $\mathrm{N}$, Nicholas $\mathrm{T}$, et al. Neutrophil gelatinase-associated lipocalin-mediated iron traffic in kidney epithelia. Curr Opin Nephrol Hypertens 2006;15(4):442-449. DOI:10.1097/01.mnh.0000232886.81142.58.

73. Zafar Mohtashami A, Hadian B, Mahmoudi GA, Anbari K, Selahbarzin A. The application of urinary NGAL measurement for early detection of AKI in hospitalized patients with poisoning. Iran J Kidney Dis 2020;14(3):206-211.

74. Rosenberg ME, Silkensen J. Clusterin: physiologic and pathophysiologic considerations. Int J Biochem Cell Biol 1995;27(7):633-645. DOI:10.1016/13572725(95)00027-m.

75. Harpur E, Ennulat D, Hoffman D, Betton G, Gautier JC, Riefke $\mathrm{B}$, et al. Biological qualification of biomarkers of chemical-induced renal toxicity in two strains of male rat. Toxicol Sci 2011;122(2):235-252. DOI:10.1093/toxsci/ kfr112.

76. Dieterle F, Perentes E, Cordier A, Roth DR, Verdes P, Grenet $\mathrm{O}$, et al. Urinary clusterin, cystatin $\mathrm{C}$, beta2microglobulin and total protein as markers to detect druginduced kidney injury. Nat Biotechnol 2010;28(5):463469. DOI:10.1038/nbt.1622.

77. El-Achkar TM, Wu XR. Uromodulin in kidney injury: an instigator, bystander, or protector? Am J Kidney Dis 2012;59(3):452-461. DOI:10.1053/j.ajkd.2011.10.054.

78. El-Achkar TM, Wu XR, Rauchman M, McCracken R, Kiefer S, Dagher PC. Tamm-Horsfall protein protects the kidney from ischemic injury by decreasing inflammation and altering TLR4 expression. Am J Physiol Renal Physiol 2008;295(2):F534-F544. DOI:10.1152/ ajprenal.00083.2008.

79. Micanovic R, Khan S, Janosevic D, Lee ME, Hato T, Srour EF, et al. Tamm-Horsfall protein regulates mononuclear phagocytes in the kidney. $J$ Am Soc Nephrol 2018;29(3):841-856. DOI:10.1681/ASN.2017040409.
80. Patidar KR, Garimella PS, Macedo E, Slaven JE, Ghabril MS, Weber RE, et al. Admission plasma uromodulin and the risk of acute kidney injury in hospitalized patients with cirrhosis: a pilot study. Am J Physiol Gastrointest Liver Physiol 2019;317(4):G447-G452. DOI:10.1152/ ajpgi.00158.2019.

81. Icer MA, Gezmen-Karadag M. The multiple functions and mechanisms of osteopontin. Clin Biochem 2018;59:1724. DOI:10.1016/j.clinbiochem.2018.07.003.

82. Kaleta B. The role of osteopontin in kidney diseases. Inflamm Res 2019;68(2):93-102. DOI:10.1007/s00011018-1200-5.

83. Lorenzen JM, Hafer C, Faulhaber-Walter R, Kümpers $\mathrm{P}$, Kielstein JT, Haller H, et al. Osteopontin predicts survival in critically ill patients with acute kidney injury. Nephrol Dial Transplant 2011;26(2):531-537. DOI:10.1093/ndt/gfq498.

84. Varalakshmi B, Kiranmyai VS, Aparna B, Ram R, Rao PVLNS, Kumar VS. Plasma osteopontin levels in patients with acute kidney injury requiring dialysis: a study in a tertiary care institute in South India. Int Urol Nephrol 2020;52(5):917-921. DOI:10.1007/s11255-02002417-x.

85. Stojanović VD, Barišić NA, Radovanović TD, Kovač NB, Djuran JD, Antić APE, et al. Doronjski AD. Serum glutathione S-transferase Pi as predictor of the outcome and acute kidney injury in premature newborns. Pediatr Nephrol 2018;33(7):1251-1256. DOI:10.1007/s00467017-3690-8.

86. Harrison DJ, Kharbanda R, Cunningham DS, McLellan LI, Hayes JD. Distribution of glutathione S-transferase isoenzymes in human kidney: basis for possible markers of renal injury. J Clin Pathol 1989;42(6):624-628. DOI: 10.1136/jcp.42.6.624.

87. Sundberg A, Appelkvist EL, Dallner G, Nilsson R. Glutathione transferases in the urine: sensitive methods for detection of kidney damage induced by nephrotoxic agents in humans. Environ Health Perspect 1994;102 Suppl 3(Suppl 3):293-296. DOI:10.1289/ ehp. 94102 s3293.

88. Shu KH, Wang CH, Wu CH, Huang TM, Wu PC, Lai $\mathrm{CH}$, et al. Urinary $\pi$-glutathione S-transferase predicts advanced acute kidney injury following cardiovascular surgery. Sci Rep 2016;6:26335. DOI:10.1038/srep26335.

89. Spada TC, Silva JMRD, Francisco LS, Marçal LJ, Antonangelo L, Zanetta DMT, et al. High intensity 
resistance training causes muscle damage and increases biomarkers of acute kidney injury in healthy individuals. PLoS One 2018;13(11):e0205791. DOI:10.1371/journal. pone.0205791.

90. Eltounali SA, Moodley J, Naicker T. Role of kidney biomarkers [Kidney injury molecule-1, Calbindin, Interleukin-18 and Monocyte chemoattractant protein-1] in HIV associated pre-eclampsia. Hypertens Pregnancy 2017;36(4):288-294.DOI:10.1080/10641955.2017.1385 793.

91. Iida T, Fujinaka H, Xu B, Zhang Y, Magdeldin S, Nameta $\mathrm{M}$, et al. Decreased urinary calbindin 1 levels in proteinuric rats and humans with distal nephron segment injuries. Clin Exp Nephrol 2014;18(3):432-443. DOI:10.1007/ s10157-013-0835-3.

92. Arulkumaran N, Sixma ML, Jentho E, Ceravola E, Bass PS, Kellum JA, et al. Sequential Analysis of a Panel of Biomarkers and Pathologic Findings in a Resuscitated Rat Model of Sepsis and Recovery. Crit Care Med 2017;45(8):e821-e830. DOI:10.1097/ CCM.0000000000002381.

93. Schrezenmeier EV, Barasch J, Budde K, Westhoff T, Schmidt-Ott KM. Biomarkers in acute kidney injury - pathophysiological basis and clinical performance. Acta Physiol (Oxf) 2017;219(3):554-572. DOI:10.1111/ apha.12764.

94. Chang CH, Yang CH, Yang HY, Chen TH, Lin CY, Chang $\mathrm{SW}$, et al. Urinary biomarkers improve the diagnosis of intrinsic acute kidney injury in coronary care units. Medicine (Baltimore) 2015;94(40):e1703. DOI:10.1097/ MD.0000000000001703.

95. Westhoff JH, Seibert FS, Waldherr S, Bauer F, Tönshoff B, Fichtner A, et al. Urinary calprotectin, kidney injury molecule-1, and neutrophil gelatinase-associated lipocalin for the prediction of adverse outcome in pediatric acute kidney injury. Eur J Pediatr 2017;176(6):745-755. DOI:10.1007/s00431-017-2907-y.

96. Ariza X, Solà E, Elia C, Barreto R, Moreira R, MoralesRuiz M, et al. (2015) Analysis of a urinary biomarker panel for clinical outcomes assessment in cirrhosis. PLoS One 2015;10(6):e0128145. DOI:10.1371/journal. pone. 0128145 .

97. Endre ZH. Recovery from acute kidney injury: the role of biomarkers. Nephron Clin Pract 2014;127;101-105. DOI: $10.1159 / 000363678$.

98. Wyler von Ballmoos M, Likosky DS, Rezaee M, Lobdell
K, Alam S, Parker D, et al. Elevated preoperative Galectin-3 is associated with acute kidney injury after cardiac surgery. BMC Nephrol 2018;19(1):280. DOI:10.1186/ s12882-018-1093-0.

99. Prud'homme M, Coutrot M, Michel T, Boutin L, Genest $\mathrm{M}$, Poirier F, et al. Acute kidney injury induces remote cardiac damage and dysfunction through the galectin-3 pathway. JACC Basic Transl Sci 2019;4(6):717-732. DOI:10.1016/j.jacbts.2019.06.005.

100. Federico G, Meister M, Mathow D, Heine GH, Moldenhauer G, Popovic ZV, et al. Tubular Dickkopf-3 promotes the development of renal atrophy and fibrosis. JCI Insight 2016;1(1):e84916. DOI: 10.1172/jci.insight.84916.

101. Zewinger S, Rauen T, Rudnicki M, Federico G, Wagner M, Triem S, et al. Dickkopf-3 (DKK3) in urine identifies patients with short-term risk of eGFR Loss. $J \mathrm{Am}$ Soc Nephrol 2018;29(11):2722-2733. DOI:10.1681/ ASN.2018040405.

102. Schunk SJ, Zarbock A, Meersch M, Küllmar M, Kellum JA, Schmit D, et al. Association between urinary dickkopf-3, acute kidney injury, and subsequent loss of kidney function in patients undergoing cardiac surgery: an observational cohort study. Lancet 2019;394(10197):488496. DOI:10.1016/S0140-6736(19)30769-X.

103. Meng XM, Tang PM, Li J, Lan HY. Macrophage phenotype in kidney injury and repair. Kidney Dis (Basel) 2015;1(2):138-146. DOI:10.1159/000431214.

104. Hoste E, Bihorac A, Al-Khafaji A, Ortega LM, Ostermann $\mathrm{M}$, Haase $\mathrm{M}$, et al. Identification and validation of biomarkers of persistent acute kidney injury: the RUBY study. Intensive Care Med 2020;46(5):943-953. DOI:10.1007/s00134-019-05919-0.

105. Schmidt IM, Hall IE, Kale S, Lee S, He CH, Lee Y, et al. Chitinase-like protein Brp-39/YKL-40 modulates the renal response to ischemic injury and predicts delayed allograft function. J Am Soc Nephrol 2013;24(2):309319. DOI:10.1681/ASN.2012060579.

106. Ohno M, Bauer PO, Kida Y, Sakaguchi M, Sugahara Y, Oyama F. Quantitative Real-Time PCR analysis of YKL-40 and its comparison with mammalian chitinase mRNAs in normal human tissues using a single standard DNA. Int J Mol Sci 2015;16:9922-9935. DOI:10.3390/ ijms 16059922 .

107. Malhotra R, Katz R, Jotwani V, Ambrosius WT, Raphael $\mathrm{KL}$, Haley $\mathrm{W}$, et al. Urine markers of kidney tubule cell injury and kidney function decline in SPRINT 
trial participants with CKD. Clin J Am Soc Nephrol 2020;15(3):349-358. DOI:10.2215/CJN.02780319.

108. Conroy AL, Hawkes MT, Elphinstone R, Opoka RO, Namasopo S, Miller C, et al. Chitinase-3-like 1 is a biomarker of acute kidney injury and mortality in paediatric severe malaria. Malar J 2018;17(1):82. DOI:10.1186/ s12936-018-2225-5.

109. Hoste EA, Vaara ST, De Loor J, Haapio M, Nuytinck L, Demeyere $\mathrm{K}$, et al. Urinary cell cycle arrest biomarkers and chitinase 3-like protein 1 (CHI3L1) to detect acute kidney injury in the critically ill: a post hoc laboratory analysis on the FINNAKI cohort. Crit Care 2020;24(1):144. DOI:10.1186/s13054-020-02867-w.

110. De Loor J, Decruyenaere J, Demeyere K, Nuytinck L, Hoste EA, Meyer E. Urinary chitinase 3-like protein 1 for early diagnosis of acute kidney injury: a prospective cohort study in adult critically ill patients. Crit Care 2016;20:38. DOI: 10.1186/s13054-016-1192-x.

111. Puthumana J, Hall IE, Reese PP, Schröppel B, Weng FL, Thiessen-Philbrook H, et al. YKL-40 associates with renal recovery in deceased donor kidney transplantation. J Am Soc Nephrol 2017;28(2):661-670. DOI:10.1681/ ASN.2016010091.

112. Ganz T, Nemeth E. Hepcidin and iron homeostasis. Biochim Biophys Acta 2012;1823(9):1434-1443. DOI:10.1016/j.bbamcr.2012.01.014.

113. van Swelm RP, Wetzels JF, Verweij VG, Laarakkers CM, Pertijs JC, van der Wijst J, et al. Renal handling of circulating and renal-synthesized hepcidin and its protective effects against hemoglobin-mediated kidney injury. J Am Soc Nephrol 2016;27(9):2720-2732. DOI:10.1681/ ASN.2015040461.

114. Choi N, Rigatto C, Zappitelli M, Gao A, Christie S, Hiebert B, et al. Urinary hepcidin-25 is elevated in patients that avoid acute kidney injury following cardiac surgery. Can J Kidney Health Dis 2018;5:2054358117744224. DOI:10.1177/2054358117744224.

115. Choi N, Whitlock R, Klassen J, Zappitelli M, Arora RC, Rigatto $\mathrm{C}$, et al. Early intraoperative iron-binding proteins are associated with acute kidney injury after cardiac surgery. J Thorac Cardiovasc Surg 2019;157(1):287297.e2. DOI:10.1016/j.jtcvs.2018.06.091

116. Scindia Y, Dey P, Thirunagari A, Liping H, Rosin DL, Floris $\mathrm{M}$, et al. Hepcidin mitigates renal ischemia-reperfusion injury by modulating systemic iron homeostasis. $J$ Am Soc Nephrol 2015;26(11):2800-2814. DOI:10.1681/
ASN.2014101037.

117. Albert C, Haase M, Albert A, Kropf S, Bellomo R, Westphal $\mathrm{S}$, et al. Urinary biomarkers may complement the cleveland score for prediction of adverse kidney events after cardiac surgery: a pilot study. Ann Lab Med 2020;40(2):131-141. DOI:10.3343/alm.2020.40.2.131.

118. Joo M, Sadikot RT. PGD synthase and PGD2 in immune resposne. Mediators Inflamm 2012;2012:503128. DOI:10.1155/2012/503128.

119. Wajda J, Dumnicka P, Sporek M, Maziarz B, Kolber W, Ząbek-Adamska A, et al. Does beta-trace protein (BTP) outperform cystatin $\mathrm{c}$ as a diagnostic marker of acute kidney injury complicating the early phase of acute pancreatitis? J Clin Med 2020;9(1):205. DOI:10.3390/ jcm9010205.

120. Saydam O, Türkmen E, Portakal O, Arıcı M, Doğan R, Demircin $\mathrm{M}$, et al. Emerging biomarker for predicting acute kidney injury after cardiac surgery: cystatin C. Turk J Med Sci 2018;48(6):1096-1103. DOI:10.3906/ sag-1704-96.

121. Oner AO, Aydin F, Demirelli S, Budak ES, Davran F, Akbas $\mathrm{H}$, et al. Clinical value of cystatin $\mathrm{C}$ and betatrace protein in glomerular filtration rate in renal transplant cases with stable renal graft functions: comparison by the 99mTc-DTPA plasma sample method. Nucl Med Commun 2014;35(7):733-744. DOI:10.1097/ MNM.0000000000000116.

122. Denning GM, Ackermann LW, Barna TJ, Armstrong JG, Stoll LL, Weintraub NL, et al. Proenkephalin expression and enkephalin release are widely observed in non-neuronal tissues. Peptides 2008;29(1):83-92. DOI:10.1016/j.peptides.2007.11.004.

123. Beunders R, Struck J, Wu AHB, Zarbock A, Di Somma S, Mehta RL, et al. Proenkephalin (PENK) as a novel biomarker for kidney function. J Appl Lab Med 2017;2(3):400-412. DOI:10.1373/jalm.2017.023598.

124. Hollinger A, Wittebole X, François B, Pickkers P, Antonelli M, Gayat E, et al. Proenkephalin A 119-159 (penkid) is an early biomarker of septic acute kidney injury: the kidney in sepsis and septic shock (kid-sss) study. Kidney Int Rep 2018;3(6):1424-1433. DOI:10.1016/j. ekir.2018.08.006.

125. Rosenqvist M, Bronton K, Hartmann O, Bergmann A, Struck J, Melander O. Proenkephalin a 119-159 (penKid) - a novel biomarker for acute kidney injury in sepsis: an observational study. BMC Emerg Med 


\section{9;19(1):75. DOI:10.1186/s12873-019-0283-9.}

126. Peterson PA, Evrin PE, Berggård I. Differentiation of glomerular, tubular, and normal proteinuria: determinations of urinary excretion of beta-2-macroglobulin, albumin, and total protein. J Clin Invest 1969;48(7):11891198. DOI:10.1172/JCI106083.

127. Murat SN, Kurtul A, Yarlioglues M. Impact of serum albumin levels on contrast-induced acute kidney injury in patients with acute coronary syndromes treated with percutaneous coronary intervention. Angiology 2015;66(8):732-737. DOI:10.1177/0003319714551979.

128. George B, Joy MS, Aleksunes LM. Urinary protein biomarkers of kidney injury in patients receiving cisplatin chemotherapy. Exp Biol Med (Maywood) 2018;243(3):272-282. DOI:10.1177/1535370217745302.

129. Bolisetty S, Agarwal A. Urine albumin as a biomarker in acute kidney injury. Am J Physiol Renal Physiol 2011;300(3):F626-F627. DOI:10.1152/ajprenal.00004.2011.

130. Ware LB, Johnson AC, Zager RA. Renal cortical albumin gene induction and urinary albumin excretion in response to acute kidney injury. Am J Physiol Renal Physiol 2011;300(3):F628-638. DOI:10.1152/ajprenal.00654.2010.

131. Dekker MS, Mosterd A, van 't Hof AW, Hoes AW. Novel biochemical markers in suspected acute coronary syndrome: systematic review and critical appraisal. Heart 2010;96(13):1001-1010. DOI:10.1136/ hrt.2009.189886.

132. Aytac Ates H, Yücetaş U, Erkan E, Yucetas E, Ulusoy $\mathrm{S}$, Kadihasanoglu $\mathrm{M}$, et al. The predictive value of ischemia-modified albumin in renal ischemiareperfusion injury. Urol Int 2019;103(4):473-481. DOI:10.1159/000500929.

133. Kocan H, Citgez S, Yucetas U, Yucetas E, Yazici M, Amasyali AS, et al. Can ischemia-modified albumin be used as an objective biomarker for renal ischemic damage? An experimental study with Wistar albino rats. Transplant Proc 2014;46(10):3326-3329. DOI:10.1016/j.transproceed.2014.11.001.

134. Garimella PS, Lee AK, Ambrosius WT, Bhatt U, Cheung AK, Chonchol M, et al. Markers of kidney tubule function and risk of cardiovascular disease events and mortality in the SPRINT trial. Eur Heart
J 2019;40(42):3486-3493. DOI:10.1093/eurheartj/ ehz392.

135. Bullen AL, Katz R, Lee AK, Anderson CAM, Cheung AK, Garimella PS, et al. The SPRINT trial suggests that markers of tubule cell function in the urine associate with risk of subsequent acute kidney injury while injury markers elevate after the injury. Kidney Int 2019;96(2):470-479. DOI:10.1016/j.kint.2019.03.024.

136. Zheng J, Xiao Y, Yao Y, Xu G, Li C, Zhang Q, et al. Comparison of urinary biomarkers for early detection of acute kidney injury after cardiopulmonary bypass surgery in infants and young children. Pediatr Cardiol 2013;34(4):880-886. DOI:10.1007/s00246-012-05636.

137. Liu X, Guan Y, Xu S, Li Q, Sun Y, Han R, et al. Early predictors of acute kidney injury: a narrative review. Kidney Blood Press Res 2016;41(5):680-700. DOI:10.1159/000447937.

138. Wang R, Hu H, Hu S, He H, Shui H. $\beta 2$-microglobulin is an independent indicator of acute kidney injury and outcomes in patients with intracerebral hemorrhage. Medicine (Baltimore) 2020;99(8):e19212. DOI:10.1097/MD.0000000000019212.

139. Barton KT, Kakajiwala A, Dietzen DJ, Goss CW, Gu H, Dharnidharka VR. Using the newer kidney disease: Improving Global Outcomes criteria, beta-2-microglobulin levels associate with severity of acute kidney injury. Clin Kidney J 2018;11(6):797-802. DOI:10.1093/ ckj/sfy056.

140. Onopiuk A, Tokarzewicz A, Gorodkiewicz E. Cystatin C: a kidney function biomarker. Adv Clin Chem 2015;68:57-69. DOI:10.1016/bs.acc.2014.11.007.

141. Filler G, Bökenkamp A, Hofmann W, Le Bricon T, Martínez-Brú C, Grubb A. Cystatin C as a marker of GFR--history, indications, and future research. Clin Biochem 2005;38(1):1-8. DOI:10.1016/j.clinbiochem.2004.09.025.

142. Shukla AN, Juneja M, Patel H, Shah KH, Konat A, Thakkar BM, et al. Diagnostic accuracy of serum cystatin $\mathrm{C}$ for early recognition of contrast induced nephropathy in Western Indians undergoing cardiac catheterization. Indian Heart $J$ 2017;69(3):311-315. DOI:10.1016/j. ihj.2016.12.010.

143. Yong Z, Pei X, Zhu B, Yuan H, Zhao W. Predictive value of serum cystatin $C$ for acute kidney injury in adults: a meta-analysis of prospective cohort trials. $\mathrm{Sci}$ 
Rep 2017;7:41012. DOI:10.1038/srep41012.

144. Porrini E, Ruggenenti P, Luis-Lima S, Carrara F, Jiménez A, de Vries APJ, et al. Estimated GFR: time for a critical appraisal. Nat Rev Nephrol 2019;15(3):177190. DOI:10.1038/s41581-018-0080-9.

145. Abbasi F, Moosaie F, Khaloo P, Dehghani Firouzabadi F, Fatemi Abhari SM, Atainia B, et al. Neutrophil gelatinase-associated lipocalin and retinol-binding protein-4 as biomarkers for diabetic kidney disease. Kidney Blood Press Res 2020;45(2):222-232. DOI:10.1159/000505155.

146. Fiseha T, Tamir Z. Urinary markers of tubular injury in early diabetic nephropathy. Int $J$ Nephrol 2016;2016:4647685. DOI:10.1155/2016/4647685.

147. Nlandu Khodo S, Neelisetty S, Woodbury L, Green E, Harris RC, Zent R, et al. Deleting the TGF- $\beta$ receptor in proximal tubules impairs HGF signaling. Am J Physiol Renal Physiol 2016;310(6):F499-510. DOI:10.1152/ajprenal.00446.2015.

148. Gui Y, Lu Q, Gu M, Wang M, Liang Y, Zhu X, et al. Fibroblast mTOR/PPAR $\gamma / \mathrm{HGF}$ axis protects against tubular cell death and acute kidney injury. Cell Death Differ 2019;26(12):2774-2789. DOI:10.1038/s41418019-0336-3.

149. Zhou D, Fu H, Xiao L, Mo H, Zhuo H, Tian X, et al. Fibroblast-specific $\beta$-catenin signaling dictates the outcome of AKI. J Am Soc Nephrol 2018;29(4):12571271. DOI:10.1681/ASN.2017080903.

150. Gattai PP, Maquigussa E, da Silva Novaes A, da Silva Ribeiro R, Varela VA, Ormanji MS, et al. miR-26a modulates HGF and STAT3 effects on the kidney repair process in a glycerol-induced AKI model in rats. J Cell Biochem 2018;119(9):7757-7766. DOI:10.1002/ jcb. 27134.

151. Lu Z, Song N, Shen B, Xu X, Fang Y, Shi Y, et al. Syndecan-1 shedding inhibition to protect against ischemic acute kidney injury through hgf target signaling pathway. Transplantation 2018;102(7):331-344. DOI:10.1097/TP.0000000000002170.

152. He J, Chen Y, Lin Y, Zhang W, Cai Y, Chen F, et al. Association study of MCP-1 promoter polymorphisms with the susceptibility and progression of sepsis. PLoS One 2017;12(5):e0176781. DOI:10.1371/journal. pone. 0176781 .

153. Haller H, Bertram A, Nadrowitz F, Menne J. Monocyte chemoattractant protein-1 and the kidney. Curr
Opin Nephrol Hypertens 2016;25:42-49. DOI:10.1097/ MNH.0000000000000186.

154. Munshi R, Johnson A, Siew ED, Ikizler TA, Ware LB, Wurfel MM, et al. MCP-1 gene activation marks acute kidney injury. J Am Soc Nephrol 2011;22(1):165-175. DOI:10.1681/ASN.2010060641.

155. Vianna HR, Soares CM, Silveira KD, Elmiro GS, Mendes PM, de Sousa Tavares M, et al. Cytokines in chronic kidney disease: potential link of MCP-1 and dyslipidemia in glomerular diseases. Pediatr Nephrol 2013;28(3):463-469. DOI:10.1007/s00467-0122363-x.

156. Moledina DG, Isguven S, McArthur E, Thiessen-Philbrook H, Garg AX, Shlipak M, et al. Plasma monocyte chemotactic protein-1 is associated with acute kidney injury and death after cardiac operations. Ann Thorac Surg 2017;104(2):613-620. DOI:10.1016/j.athoracsur.2016.11.036.

157. Bautista E, Arcos M, Jimenez-Alvarez L, GarcíaSancho MC, Vázquez ME, Peña E, et al. Angiogenic and inflammatory markers in acute respiratory distress syndrome and renal injury associated to A/H1N1 virus infection. Exp Mol Pathol 2013;94(3):486-492. DOI:10.1016/j.yexmp.2013.03.007.

158. Bihorac A, Baslanti TO, Cuenca AG, Hobson CE, Ang $\mathrm{D}$, Efron PA, et al. Acute kidney injury is associated with early cytokine changes after trauma. J Trauma Acute Care Surg 2013;74(4):1005-1013. DOI:10.1097/ TA.0b013e31828586ec.

159. Gameiro J, Agapito Fonseca J, Jorge S, Lopes JA. Acute kidney injury definition and diagnosis: a narrative review. J Clin Med 2018;7(10):307. DOI:10.3390/ jcm7100307.

160. Silver SA, Chertow GM. The economic consequences of acute kidney injury. Nephron 2017;137(4):297-301. DOI:10.1159/000475607.

161. Thongprayoon C, Hansrivijit P, Kovvuru K, Kanduri SR, Torres-Ortiz A, Acharya P, et al. Diagnostics, risk factors, treatment and outcomes of acute kidney injury in a new paradigm. J Clin Med 2020;9(4):1104. DOI:10.3390/jcm9041104.

162. Rao SN, Shenoy MP, Gopalakrishnan M, Kiran BA. Applicability of the Cleveland clinic scoring system for the risk prediction of acute kidney injury after cardiac surgery in a South Asian cohort. Indian Heart $J$ 2018;70(4):533-537. DOI:10.1016/j.ihj.2017.11.022. 
163. Mossanen JC, Pracht J, Jansen TU, Buendgens L, Stoppe C, Goetzenich A, et al. Elevated soluble urokinase plasminogen activator receptor and proenkephalin serum levels predict the development of acute kidney injury after cardiac surgery. Int $\mathrm{J} \mathrm{Mol} \mathrm{Sci}$ 2017;18(8):1662. DOI:10.3390/ijms18081662.

164. Greenberg JH, Parsons M, Zappitelli M, Jia Y, Thiessen-Philbrook HR, Devarajan P, et al. Cardiac biomarkers for risk stratification of acute kidney injury after pediatric cardiac surgery. Ann Thorac Surg 2020;S0003-4975(20)30506-3. DOI:10.1016/j.athoracsur.2020.03.010.

165. Rangaswamy D, Sud K. Acute kidney injury and disease: Long-term consequences and management. Nephrology (Carlton) 2018;23(11):969-980. DOI:10.1111/ nep. 13408 .

166. Wang Y, Bellomo R. Cardiac surgery-associated acute kidney injury: risk factors, pathophysiology and treatment. Nat Rev Nephrol 2017;13(11):697-711. DOI:10.1038/nrneph.2017.119.

167. Koza Y. Acute kidney injury: current concepts and new insights. J Inj Violence Res 2016;8(1):58-62. DOI:10.5249/jivr.v8i1.610.
168. Vanmassenhove J, Van Biesen W, Vanholder R, Lameire N. Subclinical AKI: ready for primetime in clinical practice? J Nephrol 2019;32(1):9-16. DOI:10.1007/ s40620-018-00566-y.

169. Jonsson N, Gille-Johnson P, Martling CR, Xu S, Venge $\mathrm{P}$, Mårtensson J. Performance of plasma measurement of neutrophil gelatinase-associated lipocalin as a biomarker of bacterial infections in the intensive care unit. J Crit Care 2019;53:264-270. DOI:10.1016/j. jcrc.2019.07.001.

170. Huang Y, Tian Y, Likhodii S, Randell E. Baseline urinary KIM-1 concentration in detecting acute kidney injury should be interpreted with patient pre-existing nephropathy. Pract Lab Med 2019;15:e00118. DOI:10.1016/j.plabm.2019.e00118.

171. Imai N, Yasuda T, Kamijo-Ikemori A, Shibagaki Y, Kimura K. Distinct roles of urinary liver-type fatty acid-binding protein in non-diabetic patients with anemia. PLoS One 2015;10(5):e0126990. DOI:10.1371/ journal.pone.0126990.

172. Chen JJ, Fan PC, Kou G, Chang SW, Chen YT, Lee CC, et al. Meta-analysis: urinary calprotectin for discrimination of intrinsic and prerenal acute kidney injury. $J$ Clin Med 2019;8(1):74. DOI:10.3390/jcm8010074. 